\title{
Referaat
}

\section{Hoe kunnen we de academische genees- kunde in de toekomst vorm geven?}

Aan het begin van dit millennium verschenen verschillende noodkreten over de staat van de academische geneeskunde, vooral uit het Verenigd Koninkrijk. ${ }^{1-2}$ Dit leidde in 2003 tot een oproep van de BMJ Publishing Group een campagne te starten om het probleem aan te pakken. ${ }^{3}$ Een breed samengestelde internationale groep, The International Campaign to Revitalise Academic Medicine (ICRAM), nam de uitdaging aan en ging begin 2004 voortvarend van start. ${ }^{4}$ Ongeveer in dezelfde periode werd het Forum on Academic Medicine opgericht door de Medical Royal Colleges, waarvan een rapport verscheen in november 2004.5 Beide groepen zijn het er over eens dat academische geneeskunde (of academische gezondheidszorg) bestaat uit onderwijs, onderzoek en patiëntenzorg en vooral de synergie daarvan. Andere aspecten die beide noemen zijn overdracht van onderzoeksbevindingen naar de patiëntenzorg en contact met patiënten en publiek. Centraal lijkt een tekort aan academische medische staf te staan, dat enerzijds veroorzaakt wordt door beperkte carrièremogelijkheden en anderzijds leidt tot hoge klinische werkdruk. Dit klemt des te meer, daar het aantal geneeskundestudenten dat opgeleid moet worden, toeneemt. Waar de ICRAM een grootschalige, wereldwijde projectmatige werkwijze heeft gekozen met tevoren gedefinieerde doelstellingen, analyses, instelling van taakgroepen en ontwikkeling van scenario's, ${ }^{6-7}$ heeft het Forum on Academic Medicine gekozen voor een pragmatische aanpak met concrete voorstellen voor het Verenigd Koninkrijk, zowel algemeen als per specialisme. Een deel hiervan is zeker ook relevant voor de Nederlandse situatie.

Uitgaande van het probleem van een tekort aan staf richt het rapport van het Forum on Academic Medicine de aandacht vooral op potentiële jonge staf, ongeveer de fase aan het eind van de basisopleiding of rondom een ver- volgopleiding. Diverse aspecten van onderzoek, onderwijs en patiëntenzorg worden aan de orde gesteld. De eerste aanbeveling betreft het belang een loopbaan als academisch medicus aantrekkelijk te maken. Hieraan zouden een erkend en flexibel opleidingstraject, goede begeleiding, het instellen van geoormerkte plaatsen en een helder carrièrebeleid kunnen bijdragen. Een specifieke aanbeveling ten aanzien van het (lange) opleidingstraject tot academisch medicus is meer competentiegericht te werken, zodat talent vertaald kan worden in tijdwinst. Specifiek wordt het belang van onderwijs geven genoemd. Aanbevolen wordt dat alle academische medici didactisch geschoold worden voor het geven van onderwijs in alle fases van het medisch opleidingscontinuüm. Voor diegenen bij wie het accent van hun activiteiten op onderwijs ligt, wordt een formele opleiding op dit gebied aanbevolen. Voor het waarderen van onderzoek wordt onder andere geadviseerd aparte maatstaven te ontwikkelen voor klinisch onderzoek en het gebruik van een klinisch portfolio voor het aantonen van verworven en behouden klinische vaardigheden.

Terug naar onze situatie. Zonder de pretentie te hebben deze geheel te kunnen overzien, lijkt me dat bovenstaande in grote lijnen ook hier opgaat. Enkele reeds genomen Nederlandse initiatieven die in dit verband genoemd kunnen worden, zijn de mogelijkheid van een onderwijsstage in de basisopleiding (Utrecht) en de mogelijkheid een promotietraject te combineren met de basisopleiding (Groningen) of met de vervolgopleiding (landelijk). De aandacht voor de medische opleiding als één traject, het opleidingscontinuüm, kan de specifieke training tot academisch medicus bevorderen. Tenslotte wordt door alle Nederlandse geneeskundeopleidingen gezamenlijk gewerkt aan een systeem voor de didactische kwalificatie van docenten en de relatie daarvan met een loopbaanbeleid. Kortom, er is beweging, maar er is nog veel te doen.

Ineke Molenaar, Groningen 


\section{Literatuur}

1. Goldbeck-Wood S. Reviving academic medicine in Britain. BMJ 2000;320(7235):591-2.

2. Stewart P. Academic medicine: a faltering engine. BMJ 2002;324(7335):437-8.

3. Clark J, Smith R. BMJ Publishing Group to launch an international campaign to promote academic medicine. BMJ 2003;327(7422):1001-2.

4. Tugwell P. Campaign to revitalise academic medicine kicks off. BMJ 2004;328(7440):597.

5. Academy of Medical Royal Colleges. Clinical academic medicine. The way forward. A report from the Forum on Academic Medicine [monograph op internet]. Salisbury, Wiltshire: Sarum ColourView Group; november 2004 [geciteerd op 1 augustus 2005]. Beschikbaar op: http://www.rcplondon. ac.uk/pubs/books/clinacad/ClinAcadMed.pdf.

6. International Working Party to Promote and Revitalise Academic Medicine: ICRAM (the International Campaign to Revitalise Academic Medicine): agenda setting. BMJ 2004;329(7469):787-9.

7. Clark J, for the International Campaign to Revitalise Academic Medicine: Five futures for academic medicine: the ICRAM scenarios. BMJ 2005;331(7508):101-4. 